3 Research Square

\title{
Correlation between DVH parameters and lung function changes before and after radiotherapy and the occurrence of radiation-induced lung injury (RILI)
}

Research

Keywords:

Posted Date: May 10th, 2021

DOI: https://doi.org/10.21203/rs.3.rs-57233/v2

License: (c) (i) This work is licensed under a Creative Commons Attribution 4.0 International License. Read Full License 


\section{Abstract}

The authors have requested that this preprint be withdrawn due to erroneous posting.

\section{Full Text}

The authors have withdrawn this preprint from Research Square. 